\title{
SILANG BUDAYA DAN PENDIDIKAN MULTIKULTURAL DI INDONESIA
}

\author{
Oleh \\ Firman Firman \\ Jurusan Bimbingan dan Konseling FIP Universitas Negeri Padang \\ Email : firman@konselor.org
}

\begin{abstract}
Abstrak
Negara Indonesia didiami oleh masyarakat majemuk, yang merupakan kekayaan dan sekaligus berpotensi untuk terjadinya disintegrasi antara satu etnis dengan etnis lainnya. Tulisan ini bertujuan untuk membahas silang budaya dan pendidikan multikultural di Indonesia. Karakter masyarakat dari satu etnik diperoleh melalui pendidikan, baik pendidikan di lingkungan keluarga, sekolah dan masyarakat. Kendala utama dialami masyarakat Indonesia dalam silang budaya, diantaranya: (1) rendahnya tingkat pengetahuan, pengalaman, dan jangkauan komunikasi sebagian masyarakat, (2) kurang maksimalnya media komunikasi dalam memerankan fungsinya sebagai mediator dan korektor informasi, dan (3) paradigma pendidikan yang lebih menekankan pengembangan intelektual dengan mengabaikan pengembangan kecerdasan emosional, pembentukan sikap moral, dan penanaman nilai budaya. Upaya penyelesaian permasalahan tersebut dapat dilakukan dengan membangun kehidupan multi kultural, meningkatkan peran media komunikasi, dan menginegrasikan nilai-nilai budaya tradisional dalam proses pendidikan. Pendidikan multikultural dapat diartikan sebagai sebuah proses pendidikan yang membirikan peluang sama pada semua anak bangsa tanpa membedakan perlakukan karena perbedaan etnik, budaya dan agama yang memberikan penghargaan terhadap keraman dan memberikan hak-hak sama bagi etnik minoritas dalam upaya memperkuat persatuan dan kesatuan, indentitas nasional dan citra bangsa di mata dunia Internasional. Pelaksanaan pendidikan multikultur di Indonesia dapat dilakukan melalui mata pelajaran Pendidikan Moral Pancasila, agama, sejarah, yang harus dilakukan secara komprehensif.
\end{abstract}

\section{A. Pendahuluan}

Masyarakat Indonesia terdiri dari beranekaragam suku bangsa, agama, bahasa dan kebudayaan yang dipersatukan oleh semboyang Bhineka Tunggal Ika. Suku-suku bangsa tersebut umumnya berasal dan menduduki suatu wilayah permukiman tertentu, walaupun dewasa ini sebagian anggotanya telah tersebar ke seluruh pelosok tanah air, kecuali mereka yang masih menetap di kampung 
halamannya sendiri. Warga suku-suku bangsa yang sudah berpindah ke daerah lain tersebut, dituntut hidup bersama dengan kelompok-kelompok sosial yang berasal dari berbagai suku bangsa di perkotaan dan pusat-pusat industri maupun di tempattempat mereka mencari nafkah lainnya. Kontak budaya antar berbagai suku dari latar budaya berbeda tidak jarang menyebabkan terjadinya perubahan kebudayaan dalam masyarakat.

Kemajemukan masyarakat Indonesia tidak hanya ditunjukan oleh beranekaragamnya corak kesukubangsaan dan kebudayaan secara horizontal, tetapi juga secara vertikal juga ditunjuan oleh kemajuan ekonomi, teknologi, dan organisasi sosial-politik masyarakat juga beragam. Perkembangan masyarakat dan kebudayaan masing-masing suku berbeda satu dengan lainnya. Kondisi ini disebabkan oleh letak geografis dan proses sejarah, perkembangan kerajaankerajaan besar maupun kecil dengan struktur sosial dan politik beragam serta pengaruh kebudayaan asing, sehingga melahirkan kemajemukan masyarakat Indonesia dalam berbagai budaya.

Kenyataan ditemui akhir-akhir ini di dalam masyarakat majemuk Indonesia tersebut, sering terjadi pergolakan sosial-budaya dan politik yang dapat merongrong terhadap perkembangan masyarakat dan kebudayaan, yang pada gilirannya merusak karakter bangsa Indonesia yang kehidupannya dilandasi oleh Pancasila. Konflik sosial bermunculan di berberbagai daerah silih berganti yang sulit dibendung. Bangsa Indonesia yang sebelumnya dikenal sebagai bangsa yang ramah dan memiliki tata karma, tegang rasa yang sangat tinggi, seolah berubah menjadi bangsa yang brutal dan bengis. Kerusuhan antar agama yang tidak dapat 
dibuktikan siapa pelakunya, seperti kejadian di Situbondo pada tanggal 10 Oktober 1996. Demikian pula di Tasikmalaya pada tanggal 26 Desember 1996 terjadi kerusuhan yang dipicu oleh adanya penganiayaan dua orang santri oleh polisi setempat. Selanjutnya di Ambon terjadi pula kerusuhan antar agama pada tanggal 19 Januari 1999 terjadi tepat pada pada hari raya 'Idul Fitri , di Galela, Maluku Utara terjadi pembantaian di dalam masjid pada bulan puasa Desember 1999 dan di Poso ditemukan ratusan mayat terapung di sungai Poso pada Mei 2000 menjelang pelaksanaan MTQ ke 19.

Berbagai pertikaian etnik dan agama, seperti kasus Tentena (RCTI, 28 Mei 2005), pemboman di pasar Tentena diduga ada kaitannya dengan sisa-sisa konflik sebelumnya. Antara dua kelompok agama yang berbeda atau ada pihak luar yang dengan segaja menunggangginya. Karena semenjak tahun 1999 daerah ini telah dilanda konflik antar agama yang berkepanjangan. Dewasa ini konflik horizontal telah membawa integritas keambang kritis adalah konflik antar Islam dan Kristen di Ambon. Konflik tersebut tidak saja merusak lingkungan fisik tetapi mempertajam perbedaan golongan social (golongan putih beragama Islam dan merah beragma Kristen dengan batas giografis yang jelas) pada akhirnya berimplikasi pada rusaknya karakter bangsa.Konflik sosial tidak jarang terjadi di lingkungan persekolahan, baik konflik antar pelajar sesama pelajar, guru dengan pelajar, dan sebagainya. Berbagai ketegangan yang terjadi menunjukan terjadinya perubahan kebudayaan yang mengarah kepada terkikisnya karakter bangsa Indonesia itu sendiri. 
Potensi konflik menjadi sebuah permasalahan yang beragam dalam masyarakat majemuk. Indonesia diproklamirkan sebagai negara yang memiliki keragaman etnik tetapi memiliki tujuan yang sama, yaitu sama menuju masyarakat adil makmur dan sejahtera. Akan tetapi gagasan besar tersebut kemudian tenggelam dalam sejarah dengan politik mono-kulturnya di zaman Soekarno dan Soeharto. Demokrasi terpimpin yang diusung Soekarno telah mematikan kreatifitas lokal berbasis etnik dan budaya tertentu. Begitu pula manajemen pemerintahan yang sentralistik zaman Soeharto, sehingga falsafat Bhineka Tunggal Ika, kemudian hanya menjadi slongan dan tidak pernah diwujudkan dalam teori ketata negaraan, hubungan sosial maupun pranata sosial lainnya.

Kemajemukan masyarakat Indonesia seringkali terabaikan dalam usaha pembangunan bangsa. ada anggapan apabila suatu bangsa telah lahir, baik melalui cara-cara damai atau peperangan, segalanya telah siap untuk melaksanakan pembangunan selanjutnya. Seolah-olah masyarakat itu merupakan kesatuan sosial yang utuh.

Kenyataan ditemui adanya kemungkinan ketegangan antar kelompok dalam setiap kesatuan sosial karena perbedaan dalam mengembangkan kebersamaan. Oleh karena itu, dinamika pergolakan sosial sebagai akibat pergaulan antar suku bangsa atau golongan dalam suatu masyarakat bangsa yang majemuk tidak dapat diabaikan. Selain hal itu, akan menimbulkan ketidakseimbangan sosial, sesungguhnya juga dapat memacu perubahan kearah pembaharuan yang justru diperlukan dalam membina persatuan dan kesatuan dalam masyarakat . 
Sehubungan dengan hal itu, dalam perjalan proklamasi kemerdekaan negara kesatuan Republik Indonesia yang telah mempersatukan segenap penduduk di Kepulauan Nusantara menjadi satu bangsa, telah menimbulkan berbagai tantangan yang memerlukan pendekatan khusus melalui pendidikan multikultutal dalam menanamkan kesadaran bermasyarakat, berbangsa dan bernegara kesatuan. Kamanto Sunarto (Sunarto, $2004: 47)$ menjelaskan pendidikan multikultural biasa diartikan sebagai pendidikan keragaman budaya dalam masyarakat dan terkandang juga diartikan sebagai pendidikan yang menawarkan ragam model untuk keragaman budaya dalam masyarakat dan terkadang juga diartikan sebagai pendidikan untuk membina sikap siswa agar menghargai keragaman budaya masyarakat.

Pendidikan multicultural berkembang dengan pesat pada masyarakat majemuk, Dede Rosyda $(2005 ; 1)$ menjelaskan sejarah multicultural adalah sejarah masyarakat majemuk, Canada, Australis adalah sekian negara yang sangat serius mengembangkan konsep dan teori-teori multikulturisme dan pendidikan multikultur, karena mereka adalah masyararakat imigran dan tidak dapat menutup peluang bagi imigran lain untuk masuk dan bergabung di dalamnya. Akan tetapi Negara-negara tersebut merupakan contoh Negara yang berhasil mengembangkan masyarakat multikultur dan mereka dapat membangun identitas kebangsaannya tanpa menghilangkan identitas kultur mereka sendiri.

Bertitik tolak dari uraian tersebut, menarik ditelusuri lebih lanjut melalui tulisaan ini bagaimana silang budaya dalam masyarakat dan pelaksanaan pendidikan multicultural di Indonesia. Pengkajian permasalahan tersebut sangat 
bermanfaat dalam upaya mencari solusi peningkatan kesadaran berbangsa dan bernegara kepada masyarakat Indonesia.

\section{B. Silang Budaya dalam Masyarakat Indonesia}

Kebudayaan dipahami dan dimaknai sebagai keseluruhan syistem gagasan, tindakan dan hasil karya manusia dalam rangka kehidupan masyarakat yang diperoleh melalui belajar (Koentjaraningrat, 1980 : 193). Sejalan dengan pengertian tersebut, tingkah laku manusia sebagai anggota masyarakat berhubungan dengan kebudayaan, yang diwujudkannya dalam berbagai pranata sebagai mekanisme kontrol bagi tingkah laku manusia tersebut. Geertz (1973) menjelaskan kebudayaan adalah segala sesuatu yang dipelajari dan dialami bersama secara sosial, oleh anggota suatu masyarakat. Sehingga suatu kebudayaan bukanlah hanya akumulasi dari kebiasaan (Folkways) dan tata kelakuan (mores) tetapi suatu sistem perilaku yang terorganisasi.

Masyarakat Indonesia yang terdiri dari beranekaragam suku bangsa, agama, bahasa dan kebudayaan, sudah barang tentu akan mengalami berbagai permasalahan berkaitan dengan silang budaya. Nilai-nilai yang terkandung dalam kebudayaan, menjadi acuan bertingkahlaku manusia sebagai makhluk individual yang tidak terlepas dari kehidupan masyarakat dengan orietasi kebudayaannya.

Realita menunjukkan dewasa ini, persentuhan nilai-nilai budaya sebagai manifestasi dinamika kebudayaan tidak selamanya berjalan secara mulus. Permasalahan silang buaya dalam masyarakat majemuk (heterogen) dan jamak (pluralistis) seringkali bersumber dari masalah komunikasi, kesenjangan tingkat 
pengetahuan, status sosial, geografis, adat kebiasaan. Kondisi tersebut merupakan kendala bagi tercapainya suatu consensus yang perlu disepakati dan ditaati secara luas. Ditambah lagi dengan posisi Indonesia sebagai negara berkembang, akan selalu mengalami perubahan yang pesat dalam berbagai aspek kehidupan. Persentuhan antar budaya yang terjadi secara dinamis dalam proses tawar menawar bisa mewujudkan perubahan tata nilai sebagai pergeseran budaya.

Pengembangan budaya nasional bukan didasarkan kepada konformisme budaya, tetapi lebih diarahkan pada totalitas nilai dan perilaku yang mencerminkan hasrat dan kehendak masyarakat Indonesia dalam berbangsa dan bernegara, sehingga mempunyai dua arah pokok yaitu fungsi pelestarian dan fungsi pengembangan. Fungsi pelestarian diarahkan kepada pengenalan dan pendalaman nilai-nilai luhur budaya yang bersifat universal. Sehubungan dengan hal itu , diharapkan dapat menumbuhkan dan memperkokoh rasa cinta tanah air dan kebangaan nasional. Sedangkan fungsi pengembangan diarahkan kepada perwujutan budaya nasional, yaitu perpaduan keragaman budaya tradisional ditambah dengan nilai-nilai baru yang tidak bertentangan dengan nilai-nilai universal yang berlaku dalam budaya masyarakat, guna memperkaya budaya bangsa dan mempekukuh jati diri dan kepribadian bangsa.

Masyarakat dan kebudayaannya pada dasarnya merupakan tayangan besar dari kehidupan bersama antara individu-individu manusia yang bersifat dinamis. Pada masyarakat yang kompleks (majemuk) memiliki banyak kebudayaan dengan standar perilaku yang berbeda dan kadangkala bertentangan, Perkembangan kepribadian individu pada masyarakat ini sering dihadapkan dengan model-model 
perilaku yang suatu saat diimbali sedang saat yang lain disetujui oleh beberapa kelompok namun dicela atau dikutuk oleh kelompok lainnya. Dengan demikian, seorang anak yang sedang berkembang akan belajar dari kondisi yang ada, sehingga perkembangan kepribadian anak dalam masyarakat majemuk menunjukkan bahwa pola asuh dalam keluarga lebih berperan karena pengalaman yang dominan akan membentuk kepribadian, satu hal yang perlu dipahami bahwa pengalaman seseorang tidak hanya sekedar bertambah dalam proses pembentukan kepribadian, namun terintegrasi dengan pengalaman sebelumnya, karena pada dasarnya kepribadian yang memberikan corak khas pada perilaku dan pola penyesuaian diri, tidak dibangun dengan menyusun suatu peristiwa atas peristiwa lain, karena arti dan pengaruh suatu pengalaman tergantung pada pengalaman-pengalaman yang mendahuluinya.

Masyarakat Indonesia sedang mengalami perubahan dalam berbagai aspek, diantaranya system ekonomi, polotik, sosial dan sebagainya. Kenyataan menunjukkan tidak satupun gejala perubahan sosial yang tidak menimbulkan akibat terhadap kebudayaan setempat. Kebudayaan dianggap sebagai sumber penggalaman konformisme perilaku individu dalam masyarakat pendukung kebudayaan tersebut. Kebudayaan cenderung mengulang-ulang perilaku tertentu melalui pola asuh dan proses belajar yang kemudian memunculkan adanya kepribadian rata-rata, atau stereotype perilaku yang merupakan ciri khas dan masyarakat tertentu yang mencerminkan kepribadian modal dalam lingkungan tersebut. 
Konsep watak kebudayaan sebagai kesamaan regularities sifat di dalam organisasai intra psikis individu anggota suatu masyarakat tertentu yang diperoleh karena cara pengasuhan anak yang sama di dalam masyarakat yang bersangkutan. Apabila ini dikaitka dengan konsep watak masyarakat (social character) dilandasi oleh pikiran untuk menghubungkan kepribadian tipical dari suatu kebudayaan (watak masyarakat) dengan kebutuhan obyektif masyarakat yang dihadapi suatu masyarakat.

Danandjaja (1988) ingin menggabungkan antara gagasan lama tentang sifat adaptasi pranata sosial terhadap kondisi lingkungan, dengan modifikasi karakterologi psiko analitik. Teori Erich Formm mengenai watak masyarakat (social character) kendati mengakui juga asumsi dari teori lainnya mengenai tranmisi kebudayaan dalam hal membentuk "kepribadian tipikal' atau kepribadian kolektif namun dia telah juga mencoba untuk menjelaskan fungsi-fungsi sosio historical dari tipe kepribadian tersebut. Yang menghubungkan kepribadian tipikal dari suatu kebudayaan dengan kebutuhan obyektif yang dihadapi suatu masyarakat. Untuk memuskan hubungan itu secara efektif suatu masyarakat perlu menerjemahkannya kedalam unsur-unsur watak (traits) dari individu anggotanya agar mereka bersedia melaksanakan apa yang harus mereka lakukan.

Hambatan-hambatan yang potensial dimiliki oleh suatu masyarakat yang plural dan heterogen juga dapat ditentukan dalam banyak aspek lainnya : Struktur sosial yang berbeda akan menghasilkan pola dan proses pembuatan keputusan sosial yang berbeda, pluralitas dan heterogentitas seperti diuraikan di atas juga tanpa memperoleh tantangan yang sama kerasnya dengan tantangan terhadap upaya 
untuk mempersatukannya melalui konsep negara kesatuan yang mengimplikasikan bahwa penyelenggaraan pemerintahan dilakukan secara sentralistik.

Masyarakat Indonesia yang majemuk yang terdiri dari berbagai budaya, karena adanya berbagai kegiatan dan pranata khusus dimana setiap kultur merupakan sumber nilai yang memungkinkan terpeliharanya kondisi kemapanan dalam kehidupan masyarakatta pendukungnya, setiap masyarakat pendukung kebudayaan (culture bearers) cenderung menjadikan kebudayaannya sebagai kerangka acuan bagi perikehidupannya yang sekaligus untuk mengukuhkan jati diri sebagai kebersamaan yang berciri khas. Perbedaan antar kebudayaan, justru bermanfaat dalam mempertahankan dasar identitas diri dan integrasi sosial masyarakat tersebut. Pluralisme masyarakat dalam tatanan sosial agama, dan suku bangsa telah ada sejak jaman nenek moyang, kebhinekaan budaya yang dapat hidup berdampingan secara damai merupakan kekayaan yang tak ternilai dalam khasanah budaya nasional. Permasalahan multicultural justru merupakan suatu keindahan bila indentitas masing-masing budaya dapat bermakna dan diagungkan oleh masyarakat pendukungnya serta dapat dihormati oleh kelompok masyarakat yang lain.

Masalah yang biasanya dihadapi oleh masyarakat majemuk adalah adanya persentuhan dan saling hubungan antara kebudayaan suku bangsa dengan kebudayaan lokal. Upaya penyeragaman budaya seringkali dapat memperkuat penolakan dari budaya-budaya daerah. Kondisi itu akan lebih parah bila upaya mempertahankan dan semakin menguatnya etnosentrime. Etnosentrisme secara formal didefinisikan sebagai pandangan bahwa kelompok sendiri adalah pusat segalanya dan kelompok lain akan selalu dibandingkan dan dinilai lebih rendah.. 
Etnosentrisme membuat kebudayaan diri sebagai patokan dalam mengukur baik buruknya, atau tinggi rendahnya dan benar atau ganjilnya kebudayaan lain dalam proporsi kemiripannya .

Di lingkungan masyarakat ditemukan dua kekuatan yaitu menerima perubahan dan menolak adanya perubahan. Meskipun selalu terdapat dua kekuatan, namun sejarah memperlihatkan bahwa kaum konserfatif cepat atau lambat akan terdesak untuk memberi tempat pada adanya perobahan. Proses itu seringkali tidak berjalan secara linier, tapi berjalan maju mundur. Konflik antara kaum progresif dengan kaum konserfative maupun konflik diantara kaum progresif itu sendiri.

Landasan sosial budaya masyarakat Indonesia yang bercorak pada masyarakat majemuk (plural society) perlu memperoleh perhatian dan dikaji kembali, karena ideology masyarakat majemuk lebih menekankan pada keanekaragaman suku bangsa akan sangat sulit untuk diwujudkan dalam masarakat yang demokratis dalam kehidupan berbangsa dan bernegara. Pencapaian tujuan proses-proses demokratisasi, ideology harus digeser menjadi ideology keanekaragaman budaya atau multi kulturalisme, Kemajemukan masyarakat Indonesia yang terdiri atas berbagai suku bangsa maka yang nampak menyolok dalam kemajemukan masyarakat Indonesia adalah penekakanan pada pentingnya kesukubangsaan yang terwujud dalam komunitas-komunitas suku bangsa, dan digunakannya kesukubangsaan tersebut sebagai acuan utama bagi jati diri individu. Ada sentimen-sentimen kesuku bangsaan yang memiliki potensi pemecah belah dan penghancuran sesama bangsa Indonesia karena masyarakat majemuk menghasilkan 
batas-batas suku bangsa yang didasari oleh stereotip dan prasangka yang menghasilkan penjenjangan sosial, secara primordial dan sobyektif.

Kendala utama dialami masyarakat Indonesia dalam silang budaya, diantaranya: (1) rendahnya tingkat pengetahuan, pengalaman, dan jangkauan komunikasi sebagian masyarakat sehingga rendahnya daya tangkal terhadap budaya asing, (2) kurang maksimalnya media komunikasi dalam memerankan fungsinya sebagai mediator dan korektor informasi, dan (3) paradigma pendidikan yang lebih menekankan pengembangan intelektual dengan mengabaikan pengembangan kecerdasan emosional, pembentukan sikap moral, dan penanaman nilai budaya.

Upaya penyelesaian permasalahan tersebut dapat dilakukan dengan membangun kehidupan multi kultural yang sehat, sehingga toleransi dan apresiasi antarbudaya meningkat. Selanjutnya permasalahan tersebut daapat juga diatasi dengan meningkatkan peran media komunikasi untuk melakukan sensor, strategi pendidikan yang berbasis budaya. Nilai-nilai budaya tradisional dapat terinternalisasi dalam proses pendidikan baik di lingkungan keluarga, pendidikan formal maupun non formal. Khususnya pendidikan di sekolah diperlukan adanya paradigma baru yang dapat menyajikan model \& strategi pembelajaran yang dapat menseimbangkan kehidupan masyarakat dari berbagai latar budaya.

\section{Pendidikan Multikultural.}

Dewasa ini gagasan multikultutralisme mulai masuk dunia pendidikan di Indonesia. Di sisi lain Calarry Sada (Sada, 2004;85) menjelaskan pendidikan multikultural memiliki empat makna (model), yaitu : (1) pengajaran tentang 
keragaman budaya sebuah pendekatan asimilasi kultural, (2) pengajaran tentang berbagai pendekatan dalam tata hubungan sosial, (3) pengajaran untuk memajukan pluralisme tanpa membedakan starata sosial dalam masyarakat, dan (4) pengajaran tentang refleksi keragaman untuk meningkatkan pluralisme dan kesamaan.

Gagasan pendidikan multikultural di Indonensia sendiri, sebagaimana digagas oleh H.A.R Tilaar adalah pendidikan untuk meningkatkan penghargaan terhadap keragaman etnik dan budaya masyarakat (Tilaar, 2004:137). Sementara Cony R. Semiawan memiliki perspektif terdiri tentang pendidikan multikultural, yakni seluruh kelompok etnik dan budaya mmasyarakat Indonesia memiliki hak yang sama untuk memperoleh pendidikan yang berkualitas dan mereka memiliki hak yang sama untuk mendapat prestasi terbaik (Semiawan, $2004: 40$ ). Sedangkan Azyumardi Azra (Azra,2004:20) menjelaskan bukan sesuatu yang taken for granted tapi harus diupayakan melalui proses pendidikan perhatian serius terhadap pengembangan sikap toleran, respek terhadap perebedaan etnik, budaya dan agama dan memberikan hak-hak sipil termasuk pada kelompok minoritas.

Berkenaan dengan uraian tersebut, pendidikan multikultural dapat diartikan sebagai sebuah proses pendidikan yang membirikan peluang sama pada semua anak bangsa tanpa membedakan perlakukan karena perbedaan etnik, budaya dan agama yang memberikan penghargaan terhadap keraman dan memberikan hakhak sama bagi etnik minoritas dalam upaya memperkuat persatuan dan kesatuan, indentitas nasional dan citra bangsa di mata dunia Internasional.

Implementasi pendidikan multikultural di berbagai negara berbeda. Bila melihat salah satu contoh: pendidikan multikultural di Amerika, sebagaimana 
dikutp oleh Tilaar dari hasil penelitian Banks (Tilaar, 2004:138) menjelaskan, implementasi pendidikan multikultutal di Amerika meliputi dimensi:

kurikulum, yakni norma-norma kultur yang akan disampaikan pada siswa diintegrasikan dalam sebuah mata pelajaran, dengan rumusan kompetensi yang jelas, (2) ilmu pengetahuan, yakni perumusan keilmuan dari norma dan aturan kultur yang akan disampaikan dan dirumuskan melalui proses penelitian historis dengan melihat pada pengalaman sejarah tokoh-tokoh yang sangat konsisten dalam memperjuangkan multikulturalisme, (3) perlakuan pembelajaran yang adil, yakni perlakuan dalam pembelajaran harus disampaikan secara fair dan adil, tanpa membedakan pcrlakuan terhadap rnereka yang berasal dari etnik dan strata ekonomi tertentu, (4) pemberdayaan budaya sekolah, yakni bahwa lingkungan sekolah sebagai hidden curriculum, harus memberi dukungan terhadap pengembangan dan pembiaan multikulturalisme, baik dalam penyediaan fasilitas belajar, fasilitas ibadah, layanan adminsitrasi maupun berbagai layanan lainnya.

Berdasarkan pengalaman masyarakat Amerika tersebut, prosedur yang harus ditempuh dalam implementasi pendidikan multikultur di Indonesia, melalui : penyiapan kurikulum, yakni menyisipkan berbagai kompetensi yang harus dimiliki siswa tentang multikulturalisme pada mata pelajaran yaog relevan, karena multikulturalisme baru sebuah gerakan dan belum menjadi sebuah ilmu yang komprehensif. Kemudian, diikuti dengan perumusan berbagai pendekatan yang digunakan dalam pelaksanaan pendidikan multikultural diawali dengan teori melting pot yang sering diwacanakan oleh $\mathrm{J}$ Hector seorang immigrant asal Normandia. Hector dalam teotinya menekankan penyatuaan budaya dan melelehkan 
budaya asal, sehingga seluruh imigran Amerika hanya memiliki satu budaya baru, yakni budaya Amerika

Selanjutnya ketika komposisi etnik Amerika kian beragam dan budaya kian majemuk, maka teori melting spot dikritik dan muncul teori baru yang popular dengan nama salad bowl yang dipopulerkan oleh Horace Kallen. Teori salad bowl atau teori gado-gado tidak menghilangkan budaya asal, tapi sebaliknya kultur-kultur lain di luar diakomodir dengan baik dan masing-masing memberikan kontribusi untuk membangun budaya nasional. Pada akhirnya, interaksi kultur antar berbagai etnik masing-masing memerlukan ruang gerak yang leluasa, sehingga dikembangkan teori Cultural Pluralism, yang membagi ruang pergerakan budaya menjadi dua, yakni ruang public dan private. Ruang public adalah seluruh etnik mengatikulasikan budaya politik dan mengekspresikan partisipasi social politik mereka. Dalam konteks ini mereka homogen dalam sebuah tatanan budaya .Sedangkan ruang private, yang didalamnya mereka mengekspresikan budaya etnisitasnya secara leluasa (Budianta, 2003:8-9).

Penggunaan teori tersebut di atas, bangsa Amerika berupaya memperkuat bangsanya, membangun kesatuan dan persatuan, mengembangkan kebangaan sebagai orang Amerika, Namun pada decade 1960an masih ada sebagian masyarakat yang merasa hak-hak sipilnya belum terpenuhi. Kelompok Amerika hitam, atau imigran Amerika latin atau etnik minoritas lainnya merasa belum terlindunggi hak-hak sipilnya. Atas dasar itulah, kemudian mereka mengembangkan multiculturalism, yang menekankan penghargaan dan penghormatan terhadap hahak minoritas, baik dilihat dari segi etnik, agama, ras atau warna kulit. 
Multikulturalisme pada akhirnya sebuah konsep untuk membangun kekuatan sebuah bangsa yang tersisih dari berbagai latar belakang etnik, agama, ras, budaya dan bahasa dengan menghargai dan menghormati hak-hak sipil mereka, termasuk hak-hak kelompok minoritas. Sikap apresiatif tersebut akan dapat meningkatkan partisipasi masyarakat dalam membesarkan sebuah bangsa, karena mereka akan menjadi besar dengan kebesaran bangsa.

Berdasarkan amanat UUD 1945, khususnya Pasal 32 dan penjelasannya, maka dewasa ini telah berkembang pula kebudayaan nasional yang memenuhi kebutuhan akan kerangka acuan bagi penduduk Indonesia dalam kehidupan mereka sehari-hari. Sungguhpun kebudayaan nasional itu belum sepenuhnya berkembang dan memenuhi kebutuhan akan kerangka acuan di segala sektor kehidupan masyarakat, namun pengaruhnya cukup kuat. Kuatnya pengaruh kebudayaan nasional itu, antara lain karena sebagian besar penduduk Indonesia telah menerima dan mendukungnya sebagai pedoman bersama dalam bermasyarakat, berbangsa dan bernegara, sehingga memperlancar keterlibatan mereka dalam kegiatan yang berskala nasional. Disamping itu, pengaruh kebudayaan-kebudayaan suku bangsa dan daerah terbatas lingkupnya dalam lingkungan kerabat maupun masyarakat daerah tertentu, maka kehadiran kebudayaan nasional memenuhi kekosongan akan kerangka acuan secara nasional setelah terjadinya penggusuran kebudayaan kolonial yang semula diberlakukan di seluruh daerah jajahan.

Pengembangan budaya nasional melalui pendidikan multikultural secara terencana di sekolah-sekolah di Indonesia belum dilaksanakan secara optimal. Sehubungan dengan hal itu, pendidikan multikultural di Indonesia perlu dirancang 
Will Kymlicka (Kymlicka,2000: ix), mendeskripsikan Multicultural Citizenship, pengalaman di Amerika utara, maka materi-materi seharusnya disampikan dalam pendidikan multikulural menyangkut, dengan :

I. Hak-hak individual dan hak-hak kolektif dalam masyarakat, seperti : hak untuk memeluk sebuah agama, memperoleh kehidupan yang layak, kesempatan berusaha dan yang sebangsanya. Secara kolektif, walaupun mereka berasal dari kelompok etnik minoritas dan tidak memiliki perwakilan dalam birokrasi dan lembaga legislatif, tapi mereka memiliki hak yang sama dengan kelompok mayoritas untuk menyampaikan aspirasi politiknya, mengembangkan budayanya. (Kymlicka,2000: 34).

2. Kebebasar. individual dan budaya, yakni bahwa setiap individu termasuk dari etnik minoritas memiliki kebebasan untuk berkreasi, berkarya, bahkan mengembangkan dan memajukan budayanya. Kelompok etnik mayoritas harus menghargai hak-hak minoritas untuk mengembangkan kreatifitas dan budayanya itu (Kymilcka,2000: 75).

3. Keadilan dan hak-hak minoritas, yakni seluruh anggota masyarakat memiliki hak yang sarna memperoleh keadilan dari negara, disamping memiliki hak mengembangkan kultur etniknya, termasuk etnik minoritas yang harus mampu mengelola bahasa, dan berbagai institusi sosialnya, agar tidak hilang dalam budaya kelompok etnik minoritas (Kymlicka,2000: 126).

4. Jaminan minoritas bisa berbicara dan terwakilkan aspirasinya dalam struktur pemerintahan atau legislatif. Mereka memiliki hak untuk bisa terwakili, tetapi karena sistem kepartaian, seringkali kelompok-kelompok etnik, budaya dan 
kepentingan tersebut tidak terwakili (Kymlicka,2000: 131).

5. Toleransi dan batas-batasnya, yakni bahwa etnik minoritas yang tidak memiliki wakil langsung di lembaga legislatif atau dalam lembaga birokrasi pemerintahan, harus dilindungi oleh etnik atau kelompok mayoritas yang menguasai lembaga-lembaga pemerintahan sebagai lembaga otoritatif untuk pengambilan kebijakankebijakan publik (Kymlicka,2000: 152).

Berdasarkan materi-materi tersebut, bangsa Amerika melaksanakan pendidikan multikultural dalam membangun kesdaran bernegara bagi masyarakatnya. Di Indonesia penyajian materi tersebut sebagian telah diberikan dalam mata pelajar pendidikan agama, sejarah dan pendidikan moral pancasila. Sehubungan dengan hal itu, pelaksanaan pendidikan multikultutal di Indonesia dapat diintegrasikan dengan mata pelajaran agama, sejarah dan pendidikan moral pancasila.

Pelaksanaan pendidikan multikultural di sekolah menurut James A Banks harus dilakukan secara komprehensif, menyangkut agama, ras, etnik dan budaya serta didukung oleh kurikulum yang memadai (Banks, 1997:78). Sehubungan dengan hal itu sekolah dituntut merencanakan dan mengontrol seluruh elemen sekolah yang dapat mendukung proses pendidikan multikultural dengan baik. Guru-guru merencanakan proses pembelajaran yang dapat menumbuhkan sikap multikultur siswa untuk menjadi angota masyarakat yang demokratis, menghargai hak azazi manusia dan keadilan. Sekolah diharapkan juga mempersiapkan guru yang memiliki persepsi, sikap 
dan prilaku multikultur, sehingga memberikan kontrlbusi positif terhadap pembinaan sikap multikultur para siswanya.

Berbagai strategi dapat dilakukan oleh guru dalam pelaksanaan pembelajaran multikultural, diantaranya melalui : student centered instruction, atau pembelajaran berpusat pada siswa (Moore,2001: 134). Melalui pendekatan ini guru dapat melakukan metode diskusi dengan berbagai variasi, kemudian simulasi dan game. Selanjutnya Sally Philiph (Philip, 1997: 80) mengemukakan strategi pelibatan siswa dalam belajar dalam bentuk collaborative learning (Philip, 1997: 80). . Active learning, atau belajar aktif adalah belajar yang memperbanyak akttifitas siswa mengakses berbagai informasi dari berbagai sumber, seperti : buku teks, perpustakaan, internet atau sumber-sumber belajar lain. Melalui kegiatan tersebut siswa memperoleh berbagai pengalaman yang tidak saja menambah kompetensi pengetahuan mereka, tapi juga kemampaan analitis, sintesis dan menilai informasi yang relevan untuk dijadikan nilai baru.. Belajar dengan model ini biasa disebut sebagai self discovery learning, yakni belajar menemukan sendiri. Untuk itu guru harus mampu menjelaskan tugas yang harus dilakukan siswa, tujuan, sumber informasi, cara mengolahnya, membahasnya serta menarik kesimpulan. Sedangkan collaborative learning adalah proses pembelajaran yang dilakukan bersama antara guru dengan siswanya. Guru membantu berbagai kesulitan yang dihadapi siswa, begitu pula siswa dengan siswa lainnya. Sehingga peer teaching, atau tutorial menjadi bagian penting dalam kegiatan belajar seperti ini.

Selanjutnya pendekatan cooperatif learning, yang menurut Kauchak lebih efektif daripada groupwork (Kauchak, 1998: 234). Groupwork adalah sebuah 
proses pembelajaran yang memberi kesempatan pada semua siswa untuk terlibat dalam kelompoknya dalam melaksanakan tugas yang diberikan guru. Sehubungan denegan hal itu, guru diharuskan merencanakan proses pembelajaran, diantaranya : (1) memberitahukan tugas siswa secara kelompok, (2) mempersiapkan siswa untuk melaksanakan tugas kelompok, (3) masing-masing siswa memiliki penjabaran tugas yang jelas dalam kelomoknya, (4) memberi siswa batas waktu yang jelas dan tegas dalammenyelesaikan tugas-tugas, (5) perintahkan siswa untuk menyelesaikan tugas mereka dalam kelompok.

Pelaksanaan pendidikan multikultur, melalui mata pelajaran Pendidikan Moral Pancasila, agama, sejarah harus dilakukan secara komprehensif, dimulai dari design perencanaan dan kurikulum melalui proses penyisipan, pengayaan dan atau penguatan terhadap berbagai kompetensi yang telah ada, mendesign proses pembelajaran yang bisa mengembangan sikap siswa untuk bisa menghormati hak-hak orang lain, tanpa membedakan latar belakang ras, agama, bahasa dan budaya, dan tanpa membedakan mayoritas dan minoritas. Selanjutnya pencapaian tujuan pendidikan multikultur harus dapat dikur melalui evaluasi, dalam bentuk tes, non-tes atau melalui proses pengamatan longitudinal dengan menggunakan portofolio siswa.

\section{Penutup}

Watak kebudayaan diperoleh dari cara pengasuhan anak yang sama di dalam masyarakat yang bersangkutan. Hambatan-hambatan utama dalam masyarakat yang plural dan heterogen adalah : Struktur sosial yang berbeda akan menghasilkan pola 
dan proses pembuatan keputusan sosial yang berbeda. Kendala utama dialami masyarakat Indonesia dalam silang budaya, diantaranya: (1) rendahnya tingkat pengetahuan, pengalaman, dan jangkauan komunikasi sebagian masyarakat, (2) kurang maksimalnya media komunikasi dalam memerankan fungsinya sebagai mediator dan korektor informasi, dan (3) paradigma pendidikan yang lebih menekankan pengembangan intelektual dengan mengabaikan pengembangan kecerdasan emosional, pembentukan sikap moral, dan penanaman nilai budaya. Upaya penyelesaian permasalahan tersebut dapat dilakukan dengan membangun kehidupan multi kultural, meningkatkan peran media komunikasi, dan menginegrasikan nilai-nilai budaya tradisional dalam proses pendidikan.

Pendidikan multikultural dapat diartikan sebagai sebuah proses pendidikan yang membirikan peluang sama pada semua anak bangsa tanpa membedakan perlakukan karena perbedaan etnik, budaya dan agama yang memberikan penghargaan terhadap keraman dan memberikan hak-hak sama bagi etnik minoritas dalam upaya memperkuat persatuan dan kesatuan, indentitas nasional dan citra bangsa di mata dunia Internasional. Pelaksanaan pendidikan multikultur di Indonesia dapat dilakukan melalui mata pelajaran Pendidikan Moral Pancasila, agama, sejarah, yang harus dilakukan secara komprehensif 


\section{DAFT AR BACAAN}

Aldridge, Jerry, and Renitta Goldman, (2002) : Current Issues and Trends in Education. Boston : Allyn and Bacon.

Azra, Azyumardi, (2004) : Pendidikan Multikultural; Membangun Kembali Indonesia Bhineka Tunggallka, dalam Tsaqafah, Vol. I, No.2, tahun 2003.

Banks, A, James, (1997) : Educating Citizens in a Multicultural Society, Teacher College Press. New York: Columbia University.

Budianta, Melani, (2003) : Multi/cultura;lisme dan Pendidikan Multileultural, Sebuah Gambaran Umum, dalam Tsaqafah, Vol. I, No.2, tabun 2003.

Budiono Kusumohamodjojo, (2000): Kebhinekaan Masyarakat Indonesia, Jakarta : Grasindo Jakarta

Budhisantoso, S (2002) : Pembangunan Nasional Indonesia Dengan Berbagai Persoalan Budaya Dalam Masyarakat Majemuk. Jakarta : www.paskal8.com/hasilkajian 34.htm.

Danandjaja James, (1988) : Antropologi Psikologi. Jakarta : PT. Raja Grafindo Persada.

Dede Rosyda (2005) : Pendidikan Multikultural di Indonesia Sebuah Konseptual, makalah dalam Seminar Internasional Pendidikan Multikultural. Padang : Fakultas Tarbiyah IAIN Imam Bonjol Padang.

Kauchak, Donald P., and Paul D Eggen, (1998) : Learning and Teaching, Research Based Method. Boston :, Allyn and Bacon.

Kymlicka, Will, (2000) : Multicultural Citizenship, A Liberal Theory of Minority Rights. New York : Oxford University Press.

Koentjaraningrat, (1990) : Pengantar Antropologi. Jakarta : Gramedia.

Moore, Kenneth D. (2001) : Classrom Teaching Skill,. New York : McGraw Hill.

Phillips, Sally. (1997) : Opportunities and Responsibilities; Competence, Creativity, Collaboration, and Caring, dalam, John K Roth, 'Inspiring Teaching', Anker Publishing Company, USA, 1997.

RCTI (29 Mei 2005) Dokumen Seputar Indonesia.

Suratno, Kamanto, (2004) Multicultural Education in Schools, Challenges in its Implementation, dalam Jumal Multicultural Education in Indonesia and South 
East Asia, edisi I, tahun 2004.

Sada, Clarry, (2004) : Multicultural Education in Kalimantan Barat; an Overview, dalam. Jumal Multicultural Education in Indonesia and South East Asia, edisi I, tahun 2004.

Semiawan, Conny, (2004) : The Challenge of a Multicultural Education in a Pluralistic Society; the Indonesian Case, dalam Jumal Multicultural Education in Indonesia and South East Asia, edisi I, tahun 2004.

Tilaar, H.A.R., (2004) : Multikulturalisme, Tantangan-Tantangan Global Masa Depan dalam Transformasi Pendidikan Nasional, Grasindo, Jakarta,2004. 
MAKALAH

\title{
SILANG BUDAYA DAN PENDIDIKAN MULTIKULTURAL DI INDONESIA
}

\author{
Oleh \\ Prof. Dr. Firman. MS. Kons \\ Dekan Fakultas Ilmu Pendidikan Universitas Negeri Padang
}

Disampaikan dalam Seminar Internasional Etnik Serumpun Indonesia-Malaysia Kerjasama PGSD FIP UNP Indonesia dengan Kementrian Pelajaran Malaysia dan Sekolah Rendah Bestari Zainab II No.2 Kelantan.

\section{FAKULTAS ILMU PENDIDIKAN UNIVERSITAS NEGERI PADANG \\ 2012}


